\title{
Is Alzheimer's disease an existential fragmentation or an imprisonment of mind?
}

\author{
Keywords: \\ alzheimer's disease, mind, neurophilosophy,
} neurosciences

\section{Editorial}

Alzheimer's disease is multidimensional neurodegeneration affecting the brain cortex and the subcortical centers selectively, inducing a progressive unceasing decline of the mental faculties with an early lack of intuition and strategic thinking and a tremendous loss of professional skills, resulting in marked alteration of the social performance, characterized mostly by profound disability to deal with social demands and expectations. However, the estimation of the social reactions of persons who suffer from Alzheimer's disease, even at the advanced dramatic stages of the disease, reveals that the feeling and sense of the dignity and the fundamental moral background remain unaltered in general terms, since a substantial number of patients attempt to continue to live a dignified life.

Approaching Alzheimer's disease from the neuropathological and pathophysiological points of view we enter in a long labyrinth consisted of organelles' pathology, ${ }^{1-4}$ protein and cellular interactions, ${ }^{5}$ dendritic pathology, ${ }^{6}$ alterations of protein trafficking, ${ }^{7}$ neuroinflammation, ${ }^{8}$ vascular dysfunction ${ }^{9,10}$ and cerebral hypoperfusion, ${ }^{11}$ neurotransmitters' deficiency, ${ }^{12}$ oxidative stress, ${ }^{13}$ synaptic pathology, ${ }^{14,15}$ apoptosis ${ }^{16}$ and a genetic background implicating A-beta peptide, Tau protein, immunity and lipid processing. ${ }^{17}$ All those factors contribute in plotting the enigmatic and tragic clinical profile and social course of patients who suffer from Alzheimer's disease.

From the Neurophilosophical point of view is essential to attempt to approach the real existence of the patient who suffers from Alzheimer's disease, endeavoring to understand his or her unique inner essence, as a human being ${ }^{18}$ with all the existential and ethical dimensions, the functional boundaries and the eventual complexities of the bio-socio-psychological profile of the disease. Definitely, the serious decline of the cognition is the most severe type of existential enclosing, since thinking should be considered as an essential existential property of the human being, who as a rule, "includes his thoughts in his life. ${ }^{19}$

In addition, the memory loss of the suffering person and the difficulty in creating harmonious and effective interactions and dialogue with the society increases the social and the emotional isolation of the Self. ${ }^{20}$ Particularly, the serious memory decline slackens off the links across time that may maintain the sense of existential coherence across time ${ }^{21-23}$ and causes considerable limitation of the ability of the suffering persons to be functioning in personal and public life, narrowing down their psychosocial dimensions of activity in concrete situations and perspectives considerably. ${ }^{24}$

The expression of the being in the society is mostly related to the inner power of the soul, ${ }^{25}$ the culture of the individual, the proper time, the social interactions,${ }^{26}$ the historical and cultural situations and mainly the integrity of the mental faculties, which are depended upon the brain's function ${ }^{27}$ Although the morphological and functional alterations of the dendrites, the dendritic spines and the synapses may

\author{
Volume 9 Issue $3-2019$
}

\author{
Stavros J Baloyannis \\ Aristotelian University, Research Institute for Alzheimer's \\ disease, Greece
}

Correspondence: Stavros J Baloyannis, Professor Emeritus, Aristotelian University, Angelaki 5, Thessaloniki 5462I, Greece, Tel +3023 I0270434, Fax +3023 I0270434,

Email sibh844@otenet.gr

Received: May 26, 2019 | Published: May 27, 2019

interpret the somber phenomenology of the dementia and throw some light in the social drama of the cognitive decline of the patients who suffer from profound intellectual disabilities, however they can't give a reasonable and philosophically acceptable answer in the fundamental problem of the condition of the human hypostasis in dementia.

It is obvious that the memory loss in dementia and the spatialtemporal alterations detach the self from the past and isolate it in the very limited time of the short temporality, without further perspectives for the future. On the other hand, neuropsychological evidence demonstrates that demented persons, lacking access to autobiographic and episodic memory, can preserve the personality knowledge and retain their personal physical and spiritual identity, which may be available and still functional in lack of memory, despite the fact that person's social identity is maintained principally by the links which join that person's former social state with his present one. ${ }^{28}$

Personal identity may be based on subjective concept of the body, as physical existence, as well as on the memories and the character of the ethical worth and values of the interior life of each individual, which determine and control the right decisions and the harmonious behavior through his or her encounter with others.

An important issue in dementia is the quality of the interior life, consisted of the harmony, the peace, the interior freedom and the integrity of the moral principles of the amnesiac person. It is well known that the interior life is mostly approachable and understandable by the verbal, artistic and social behaviour and the multiple interactions of the individual with the social environment. Therefore, the criteria of the character and the quality of the interior life are mainly based on the phenomena and not on the existential dimensions and the genuine existential substrate of the self.

We have the feeling that the human being, who is not submerged in the mass or depressed by social adversities could be able to cultivate virtues and aims peacefully, even in condition of severe memory impairment, whenever intentionality is not required. The being of the patients is the real existential entity, expressing the ontological truth, which is an absolute and unaltered eternal value ${ }^{29}$

Nevertheless, the frequent depression at the initial stage ${ }^{30,31}$ of 
Alzheimer's disease may reflect the grief for the ongoing dysfunction, the loss of skills, the loss of perspectives, the lack of the capacity for self organization and the fear of the eventual social and emotional isolation, which is a painful feeling associated frequently with the physical weakness and inability. That insight of the ongoing mental tragedy is a strong evidence of an active interior life, even at the advanced stages of the disease. ${ }^{32}$ At the same time, the concept of the good and evil as well as the dignity of the personhood are unaffected evidently by the loss of memory and the impairment of learning. The moral aspect of the life remains still unchanged in the majority of the cases, in spite of the decline of the mental faculties.

The social isolation is a serious traumatic factor, accelerating the mental and psychological deterioration of the demented people, given that emotional support and compassion are substantial sources of human wellbeing. Patients, who are admitted in institutions for elderly people or nursing homes, feel isolated totally, with their own mental shape and separate existence, living in a lamentable condition of emotional starvation, far from their children, relatives and friends, declining soon to a stage of institualization, without any meaning, fulfillment or rational motivation. ${ }^{33}$

Some of the patients, who can express themselves by painting, even by very simple drawings and self-portraits, a fact which is evocative of the existing sense of self body and self identity ${ }^{34}$ can exteriorize their inner sorrowful life and their response to unpleasant factors of their endless stagnation. ${ }^{35,36}$ It is reasonable, that the patients' insight of the mental and existential tragedy is a considerable evidence of the still existing active interior life. ${ }^{37}$

By treating hundreds of demented patients in a period of more than thirty years we have the feeling that a phenomenological approach of dementia is not sufficient for a deeper understanding of the Self in dementia and for an authentic estimation of the quality of the interior life of the patients. We have noticed that in a substantial number of patients their religious or spiritual beliefs, which influence the quality of their interior life, remain unchanged until the very advanced stages of the disease.

Patients suffered from advanced dementia have serious difficulty in their meaningful communication and dialogue with other people, but they retain their ability to pray, to keep their metaphysical perspectives and to show the beauty of their soul by their meaningful face expression.

We would have thought that the ethical being may remain unaffected by the debilitating process of dementia and only the social being based on the experience, the education, the skills and the confrontation of the problems in a social context carries the signs of the mental decline. Also we do not know how the sense of the psychosomatic unity in seriously demented patients is. Apart from Cartesian dualism, ${ }^{38}$ claiming a split between mind and body, neurophilosophy pleads in favor of the harmonious psychosomatic unity as a substantial existential property. The way that the demented patients perceive their own body might reflect the way they relate to their own existence. ${ }^{39}$

We strongly believe that the quality of life is based primarily on the interior life, which even in dementia may retain the inner peace, the personhood's dignity and the principal moral and spiritual values.

\section{Acknowledgments}

None.

\section{Conflicts of interests}

Author declares there are no conflicts of interest.

\section{References}

1. Baloyannis SJ. Mitochondrial alterations in Alzheimer's disease. $J$ Alzheimers Dis. 2006;9(2):119-126.

2. Baloyannis SJ. Mitochondria in Alzheimer's disease: An Electron Microscopy Study In: Alzheimer's Disease \& Treatment Volume 2. Chapter 3, p.1-17, ISBN: 978-93-87500-60-0.

3. Baloyannis S. The Golgi apparatus of Purkinje cells in Alzheimer's disease. In: Neuropathology Back to the Roots, J Bohl, Editor. Aachen, Germany: Shaker Vertag; 2002. p. 1-10.

4. Joshi G, Bekier MI, Wang Y. Golgi fragmentation in Alzheimer's disease. Front Neurosci. 2015;9:340.

5. Boza-Serrano A, Yang Y, Paulus A, et al. Innate immune alterations are elicited in microglial cells before plaque deposition in the Alzheimer's disease mouse model 5xFAD. Sci Rep. 2018;8(1):1550.

6. Baloyannis SJ. Dendritic pathology in Alzheimer's disease. J Neurol Sci. 2009;283(1-2):153-157.

7. Baloyannis SJ. Golgi apparatus and protein trafficking in Alzheimer's disease. J Alzheimers Dis. 2014;42:S153-S162.

8. Sochocka M, Zwolinska K, Leszek J. The infectious etiology of Alzheimer's Disease. Curr Neuropharmacol. 2017;15(7):996-1009.

9. Baloyannis SJ, Baloyannis IS. The vascular factor in Alzheimer's disease: A study in Golgi technique and electron microscopy. J Neurol Sci. 2012;322(1-2):117-121.

10. Di Marco LY, Venneri A, Farkas E, et al. Vascular dysfunction in the pathogenesis of Alzheimer's disease - a review of endothelium-mediated mechanisms and ensuing vicious circles. Neurobiol Dis. 2015;82:593606.

11. Daulatzai MA. Cerebral hypoperfusion and glucose hypometabolism: key pathophysiological modulators promote neurodegeneration, cognitive impairment, and Alzheimer's disease. J Neurosci Res. 2017;95(4):943972.

12. Bierer LM, Haroutunian V, Gabriel S, et al. Neurochemical correlates of dementia severity in Alzheimer's disease: relative importance of the cholinergic deficits. J Neurochem. 1995;64(2):749-760.

13. Atwood CS, Huang X, Moir RD, et al. Role of free radicals and metal ions in the pathogenesis of Alzheimer's disease. Met Ions Biol Syst. 1999;36:309-364.

14. Manyevitch R, Protas M, Scarpiello S, et al. Evaluation of Metabolic and Synaptic Dysfunction Hypotheses of Alzheimer's Disease (AD): A MetaAnalysis of CSF Markers. Curr Alzheimer Res. 2018;15(2):164-181.

15. Baloyannis SJ, Manolidis SL, Manolidis LS. Synaptic alterations in the vestibule-cerebellar system in Alzheimer's disease- a Golgi and electron microscope study. Acta Otolaryngol. 2000;120(2):247-250.

16. Radi E, Formichi P, Battisti C, et al. Apoptosis and oxidative stress in neurodegenerative diseases. J Alzheimers Dis. 2014;42 Suppl 3:S125S152.

17. Kunkle BW, Grenier-Boley B, Sims R, et al. Meta-analysis of genetic association with diagnosed Alzheimer's disease identifies novel risk loci and implicates Abeta, Tau, immunity and lipid processing. Nat Genet. 2019;51(3):414-430.

18. Erickson EH. The prob1em of ego identity. JAm Psych Ass. 1965;4(1):56121. 
19. Kierkegaard S. Joumal 109. In Hong Hv and Hong EH: Søren Kierkegaard `s Jouma1s and Papers, B1oomington. 1967-1977.

20. Hume D. A Treatise of Human Nature. In: Selbyigge LA, editor. Clarendon: Oxford; 1960.

21. Hudson R. Dementia and personhood: a living death or alive in God? The Australian and New Zealand Theological Review. Colloqium. 2004;36:2.

22. Antonovsky A. Health, Stress and Coping. London: Jossey-Bass; 1985.

23. Ventegodt S, Flensborg-Madsen T, Andersen NJ, et al. The life mission theory VII. Theory of existential (Antonovsky) coherence: a theory of quality of life, health, and ability for use in holistic medicine. Scientific World Journal. 2005;5:377-389.

24. Ventegodt, S. The life mission theory: a theory for a consciousness-based medicine. Int J Adolesc Med Health. 2003;15(1):89-91.

25. Aristotle Ethica Nicomach. 1103 b 27.

26. Altman I. Environment and social behavior: Privacy, personal space, territory, and crowding. New York: Irvington Press; 1981.

27. Kandel Eric. Cellular Basis of Behavior. San Francisco: WH. Freeman; 1976.

28. Parfit D. Personal Identity. The Philosophical Review. 1971;80(1):3-27.

29. Baloyannis SJ. A message from Parmenides of Elea to the universal man. Encephalos. 2004;41(2):1-12.
30. Agbayewa MO. Earlier psychiatric morbidity in patients with Alzheimer's disease. J Am Geriatr Soc. 1986;34(8):561- 564.

31. Zubenko GS, Zubenko WN, McPherson S, et al. A collaborative study of the emergence and clinical features of the major depressive syndrome of Alzheimer's disease. Am J Psychiatry. 2003;160(5):857- 866.

32. Baloyannis SJ. The existential agony. Gregory Palamas. 1987;70:30-38.

33. Delislea MA. What does Solitude Mean to the Aged? Canadian Journal on Aging. 1988;7(4):358-371.

34. Chatterjee A. Prospects for a cognitive neuroscience of visual aesthetics. Bulletin of Psychology and the Arts. 2004;4:55-60.

35. Maurer K, Prvulovic D. Paintings of an artist with Alzheimer's disease: visuo-constructural deficits during dementia. J Neural Transm. 2004;111:235-245.

36. Mimica N, Dubravka K. Art therapy may be beneficial for reducing stress-related behaviors in people with dementia. Psychiatr Danub. 2011;23(1):125-128.

37. Putnam H. The meaning of meaning. In: Putnam H, editor. Mind, Language, and Reality. London: Cambridge University Press; 1975.

38. Descartes R. Paris: Traité de l'homme. 1662.

39. de Unamuno Miguel. Del sentimiento tragico de la vida. Ed. Planeta De Agostini; 1993. 